\title{
Ecosemiotic aspects of zoomorphic metaphors: The human as a predator
}

\author{
Ariel Gómez Ponce \\ CONICET-Facultad de Lenguas \\ Universidad Nacional de Córdoba \\ Argentina \\ e-mail: ariel.gomezponce@fl.unc.edu.ar
}

\begin{abstract}
Through history, predatory features are used to constructs when constructing textual representations on the human/animal frontier. The predatory act has remained a recurring motif that emerges from a metaphoric system in cultural imagination. An ecosemiotic approach to this topic allows us to understand how specific predatory behaviours constitute a source of meaning: in other words, how an alleged "animal tendency" is appropriated (translated) into various cultural texts through metaphors, creating a rhetorical order. To illustrate this, some features of metaphors of predatoriness in certain texts in Argentinian culture will be reviewed. A particularly vivid example is provided by two species, the cougar and the jaguar, that have generated cultural translations which expand and proliferate into contemporaneity. These translations constitute a form in which culture metaphorizes aggressiveness and interprets certain species from a historical and ideological perspective. The Argentinian cases suggest a revision of how history has treated the cultural other in terms of cultural and biological inferiority.
\end{abstract}

Keywords: metaphor; predation; rhetorical order; Argentinian culture

\section{Introduction}

The semantic diversity in culture indicates that the human-animal frontier is a paradigm that crosses cultures and times. Since ancient times, humans have tried to explain various phenomena through animal representations: in other words, animals signify our own experience of the world (Baker 1993: ix). It is possible to examine the question of the "limits of the human" (Barei 2013: 215) by studying the metaphorical system which allows us to think of ourselves as part of the animal world and to ask what kind of cognitive, morphological and physiological aspects draw us closer to or differentiate us from other living beings. In this work, I theorize about metaphor, understood by Juri Lotman (1990: 44) as a way to build knowledge through different cultural languages. 
Due to cultural dynamics, metaphors move freely in synchrony and diachrony, enabling us to produce different metaphors on the basis of the same referent and to make visible different ideologies. From this point of view, animal metaphors produce similarity, displacement and substitution with nature, relating animalistic features to different subjects in certain social contexts. Between the domains of culture and nature, rhetorics could be interpreted as a mechanism of meaning-generation which constitutes textual encounters. In this regard, I argue that one possible view to the use of animal metaphors could be sought in the metaphorical consideration of the human being as a predator, associating the ecological notion with certain social behaviours.

\section{Zoomorphic metaphors: Between human and animal behaviour}

First of all, natural sciences have defined the category of predation based on the form of eating in the interspecific activities as an interaction determined by a feeding strategy that allows the survival of the organism - predator - due to the consumption of another one - prey (cf. Barbosa and Castellanos 2005: 1). According to the ecologist Paul Colinvaux (1978: 155), a predator is understood as an agent who contributes to the environmental balance, because every organism must adapt its dietary structure on account of the environmental availabilities. In this sense, predation is defined by the type of food (whether it be from the same species or not) and the method of intake (Kruuk 2002: 43). Meanwhile, ethology searched for common features among various species of the natural world, defining the predatory act through patterns of behaviour that make the basic process of ingestion complex and establish a state of equilibrium (Lorenz 2005: 22).

These aspects of defining predation have allowed us to ask if it is possible that humans have an analogous matrix of behaviour with certain natural hunters. Anthropology and paleontology have tried to explain the hypothesis of 'man as a predator' over the past century. In order to study the primitive hunter and his carnivorous diet, scholars found themselves immersed in the discussion of the evolutionary leap that separated humans from other animals. The invention of weapons by the ancient hominids could have involved some "irreversible cultural moments" that made us a superior species (Ardrey 1976: 171). In this context, scientists have tried to find similar features between the behaviour of humans and natural predators in order to verify the thesis of a shared instinctive base: a series of morphological and phylogenetic features that predispose man (and animals) to an aggressive act. For this reason, Erich Fromm (1992: 143) emphasizes from a psychological perspective that there is an aggressive background which is common for humans and animals. 
In this sense, within scholarly discourse the notion of predation is studied by tracing cultural practices that seem analogous to aggressive animal behaviour. As Juri Lotman (1987: 46) states, it is probable that early hominids "communicated" a complex type of information by imitating skills and behaviours of a predatory animal: dressing in the skins of captured prey; copying poses, movements and practices of wild hunters; and turning their sounds into cries of triumph, etc. According to Lotman, these are forms that have a "character of dialogue" (Lotman 2004: 27) with the natural world. The ability to mimic the movement of some animals is an act that gave our ancestors a possibility to communicate with other species. However, what seems more important in cultural practices of mimicry is the use of semiotic mechanisms "which connect humans with the rest of the nature and which have shaped out cultural consciousness and understanding of nature in general" (Maran 2001: 334).

With the ability to generate complex models of the environment and its subjects and to communicate a more sophisticated type of information, it is probable that early humans apprehended animal behaviour and became, in their cultural representations throughout history, predators. Thus, predator metaphors of humans can be considered a cultural appropriation that has made possible the translation of a number of natural strategies, connecting us communicatively with the behaviour of the predatory animal and thus implementing a metaphorical translation. According to Robert Sommer and Barbara Sommer, the investigation of zoomorphic metaphors identifies aspects of human personalities, connoted in the relation to animal species which "can help define those qualities that are seen as separating humans from other species, at least in folk speech" (2001: 238). There are meanings in these metaphorical expressions which overlap with negative connotations in everyday texts, and show certain perception of an "animal nature". As Steve Baker (1993: 83) states, these metaphorical constructions of animality can be explained through binary oppositions: the term is represented with a negative connotation because of its association with the image of a cultural other. In the sense of George Lakoff and Mark Johnson (1980: 61), these uses of animal expressions manifest some metaphorical systematicity that expresses conceptions of how we understand a cultural identity by its social, economic or cultural aspects.

In my research (Gómez Ponce 2013, 2014), I have been interested in reviewing how humans have made use of predatory features in order to generate metaphors. In particular, I refer to the study of the metaphorical system that constructs figures on the human/animal frontier: using fictional subjects, forms of human violence are semiotized in animal key and certain social behaviours that are not adopted to the canon of "normality" are connoted. In other words, these constructions imply a metaphorical operation which establishes natural hunters as the source domain. As a cultural category, the predator works well as a "bridge" between practices of nature 
and culture, binding different social forms of human violence (sexual, moral, legal, political). Therefore, this configures a series of predatory figures that problematize the human condition, such as rapists, murderers, monsters, femme fatales or international companies.

It is important to note that, originally, the term predator was linked to war as the action of pillage or taking loot. This meaning is indicated by its Latin root praedor. It comes from the Indo-European origin, ${ }^{*}$ ghend, which refers to the act of grasping, grabbing or taking something with the hand (Roberts, Pastor 1996: 62). It is highly probable that the emergence of the word is due to the onomatopoetic sound of the rubbing of an object (stone, wood) with the hand (Gómez de Silva 1985: 560). In its primary sense, predator implies the link with the object taken, the prey.

The literature on predation metaphors is vast. For instance, as proposed by Caroline Tipler (2013: 24), it is possible to find common animalistic metaphor frameworks which inform about "behavioural intentions" and therefore criticize a hypothetical human nature (e.g. the aggressive predator and the submissive prey). Tipler emphasizes that zoomorphic metaphors shaped behavioural responses that "allowed to determine the degree to which perception and behaviour are molded by each form of animalistic dehumanization" (2013: 7). In political sense, Stacy Bergstrom Haldi (2003: 7) states that predation metaphors are used to depict government power in armed conflicts. When discussing different aspects of war from the Napoleonic period to World War II, Haldi argues that predation functions as a metaphor for an aggressive behaviour, an aspect that might explain different signifiers related to certain economic and social conditions. Zoomorphic metaphors also structure certain types of violent acts in psychological terms, for example in some representations of criminals constructed as cultural stereotypes (Douard, Schultz 2012: 35).

Based on these theories, it is interesting to note that an interpretation of human behaviour as predation is inevitably linked to the manifestation of violence in a "wild world". For instance, classifying serial murderers or sexual offenders in zoomorphic terms implies a reflexive (instinctive) aggressiveness. Consequently, as Silvia Barei (2013: 216) argues, considering the notion of 'the human' and the ways in which we incorporate the cultural other into new spaces, it is possible to explain how humankind may represent itself in its animalistic configurations. For this purpose, I study how otherness is produced and processed discursively, particularly under the notion of predation. My hypothesis posits that linking cultural subjectivities to natural species can be considered as an act of creation as well as of alienation.

In order to investigate these connections, in the Grupo de Estudios de Retórica (research team settled in the Universidad Nacional de Córdoba, Argentina) we have theorized about the metaphor, understanding it in its classic sense as a translatio that 
enables the transference of meaning. Our research team understands metaphor as a way of building knowledge through different cultural languages. Across cultural dynamics, there is a "rhetorical order" allowing tropes to move freely synchronically and diachronically, producing different metaphors and different ideologies (Barei et al. 2006: 28; Barei, Gómez Ponce 2014). From this perspective, metaphors produce operations of similarity or displacement which circulate historically and in different social contexts. Thus, every rhetorical construction is not an entity that "reflects" the world but also a condition that allows the access to it. According to Silvia Barei and Pablo Molina Ahumada (2008: 12), the rhetorical order involves a semiotic-structural organization within culture: a "complex system" constructed by multiple texts with different modelling of the world. In this sense, a trope, such as metaphor, is not merely a figure of speech but a way of understanding the world and translating that which cannot be expressed through denotation. From this semiotic point of view, rhetorics is interpreted as a mechanism of meaning-generation which comprises of textual encounters and intersections of different semantic levels. This interpretation is in line with Juri Lotman's (1990: 44) ideas, in which metaphor is born "at the point of contact between two languages": in other words, it is a translation of meanings, belonging to the whole semiotic sphere and not just the artistic one.

Although philosophy (Nietzsche 2012[1873]; Ricoeur 1975), linguistics (Lakoff 2004; Gibbs 1994), literary theory (de Man 1979; Genette 1996) and general semiotics (Kristeva 1982; Barthes 2009[1986]) have been interested in the function of metaphor, in this paper I focus on a new theoretical relationship. From the point of view of ecosemiotics, the predatory act has remained in the cultural imagination as a recurring motif, which makes visible an "animalistic tendency" (Lotman 2004: 30 ) in numerous artistic and discursive representations that emerge from a metaphorical understanding. Proposed by Winfried Nöth (1996), ecosemiotics is a field where classic semiotics and natural sciences intersect. Ecosemiotics studies the semiotic relations between culture and nature, such as how humans build their own "imaginary nature". It also investigates the human attempt to live with other species and the semiotic relationship between beings and their environment. Through the creation of different models of the natural world, it is possible to understand what semiotic mechanisms determine the place of nature and living beings in human culture. It is what Kalevi Kull (1998: 355) calls a 'second' nature: a cultural modelling of the natural world.

In light of these theories, I aim to show how the predator metaphor is the key to considering the human/animal tension and to conceiving the proximities and distances with other beings in the natural world as well as in the cultural world. As Kalevi Kull (1998: 351) posits, ecosemiotics is part of the cultural semiotics since the manner in which humans interpret nature is always crossed by socio-historical 
models. In other words, it is a process of culturization of the natural space and the elements and organisms that inhabit it. Through an ecosemiotic perspective, it is possible to study the modes of categorization, contextualization and signification of the elements in the representation of the relation between culture and nature. Following this logic, ecosemiotics makes it possible to investigate the rhetorical mechanisms, which that have been creating the cultural other in animalistic terms since ancient times, with the use of diverse logics of equivalences and differences between the animal and the human. Therefore, the articulation of ecosemiotics and the field of cultural semiotics enable me to analyse the fictionalization of historical subjects which seem to be in tension with the animal. In other words, I seek to investigate how culture reproduces metaphors in scientific, artistic, mythological and everyday life orders that shed light on the semiotic mechanisms with which we interpret the natural world.

In this sense, ecosemiotics makes it possible to understand "how human culture interprets nature" in its textual representations (Nöth 2001: 73). From a methodological point of view, ecosemiotics allows to investigate how specific behaviours are a source of meaning: in other words, how through metaphors an alleged "animal manifestation" is appropriated by (translated into) various cultural texts. To illustrate this, I am interested in reviewing some features of predatory metaphors in certain texts of Argentinean culture that have caught my attention.

\section{The predatory Argentina}

It is highly probable that in the formative period of culture (a "semiotic zero", according to Lotman 2000: 194), early hominids learned certain practices from predatory animals in order to survive in a hostile environment: in other words, the appropriation of animal behaviour through cultural mechanisms took place. In this context, it is interesting to consider how some natural predators become objects of representation in textual configurations which can be interpreted as cultural translations of this primitive "semiotic moment" (Martinelli 2010: 10). For instance, it is possible to observe this signification through Latin American history and particularly in Argentinean culture. In this sense, such examples can be found especially in two species present throughout the American continent: the cougar ('puma concolor' or 'puma' in Spanish) and the jaguar ('pantheraoca' or, as it is known in South America, 'yaguareté). These are two carnivore felines, top predators whose natural environments (the former in the mountain, the latter in the jungle) are located throughout the vast territory of Argentina and many other countries in the vicinity. The cougar and the jaguar, often confused, have been objects of cult and 
admiration for the native civilizations (that is, among pre-Columbian communities such as Aztecs, Quechuas, Aymaras, Aguadas and Cienagas, among others). The cultural signification of both predators has generated semiotic meanings that expand into contemporaneity as a form in which human culture metaphorizes aggressiveness.

As it was described above, cougars and jaguars were supreme predators until they came across humankind. Since hunting implies a method of survival, it is reasonable to think that these kinds of animals became the central point of mythological representations in cults and rituals. According to Vladimir Toporov (2002), animals possess a great semantic importance in these early stages of culture, when humanity could not yet be separated from other species. For this mythologist, in this mythological model of the world, the hunting scheme (hunter-subject/prey-object) is established as the most recurrent paradigm at the beginnings of culture. It is highly probable that the use of predatory metaphor has its origins in a mythical modelling that is invigorated and recovered in more contemporary texts: cultural productions set in a "mythological order" (Barei, Molina Ahumada 2008: 10). This gives rise to the questions: how did both mythical species (the cougar and the jaguar) reappear at different historical moments of Argentinean culture? How did humanity recover its hunting past at specific cultural moments? Why do we still think of ourselves as predators? In order to shed some light on these points, I will focus on three instances of metaphorical uses.

First of all, let us remember that Argentina was inhabited by many aboriginal communities, some of which are still present, albeit in small numbers. Closely related to the Inca culture, the Quechua integrates indigenous traditions and ethnic groups, located in many countries in South America such as Chile, Bolivia, Peru and Argentina. Most of these cultures disappeared after the Spanish colonization, leaving only a small population spread across the present national territories. However, many aspects of their culture remain in contemporaneity in the form of traditions, social practices, art forms, linguistic vestiges and, of course, local legends and mythological texts. An example of this is a legendary character that interprets the human/animal tension in terms of metamorphosis: the 'Runa-Uturunco' (the were-cougar or werejaguar in Quechua language).

We must not forget that the figure of the jaguar and the puma were of paramount importance to the cosmology of many aboriginal cultures. In general, felines were considered totemic figures that responded to a divine interpretation: warriors, shamans and personifications of gods (Valverde Valdés 1996). As a matter of fact, there are many archaeological findings showing iconographic importance of these animals in the pre-Columbian cultures. As it was previously mentioned, the jaguar and the cougar are often confused because of the similarities in size, speed of movement, and risk to humans. As a consequence, it is logical that both figures 
are interlaced in this mythological thinking. According to the anthropologists Tom Dillehay and Peter Kaulicke (1984), felines had a cognitive significance that determined social, economic and spatial ${ }^{1}$ behaviours in these cultures. For these authors, it is possible to consider that "these animals may have been didactic elements for humans in order to relate, organize and symbolize their own social experiences" (Dillehay, Kaulicke 1984: 29, my translation, A. G. P.). The semiotization of these species and their translation into zoomorphic metaphors establishes a magical modelling, a feature of the relationship between the humankind and nature since ancient times (Nöth 1996).

As far as a mythological/magical order is concerned, the Runa-Uturunco explains an Aboriginal reality that is still operating in the imagination of the Argentinians and many other countries of South America. This mythological character of Northwestern Argentina is a peasant that at nights becomes what we locally call 'mountain lion' and hunts animals and humans alike (Bossi 2004: 18). Through a diabolic pact ${ }^{2}$, the Runa-Uturunco is human in the day and a puma at night. The mythological being alternates between both shapes as a result of a ritual: he wallows on a piece of cougar skin, the amulet that allows the metamorphosis. In this regard, it is known that the skin of felines like leopards, lions or panthers are of great importance to the figure of cultural heroes (Ivanov 2002: 238). The mythical tradition indicates that there is a special "vital force" in the skin of an animal. In this sense, the Homeric characters have given us numerous examples such as Menelaus' lion skin in The Iliad. Locally, another case of metamorphosis can be found in the jaguar warriors ('guerreros jaguar'), which were a kind of special forces in the Aztec culture who wore the skin of these animals on their shoulders. It seems that there is some resemblance between ancient warriors, primitive hunters and the figure of the Runa-Uturunco who wore the skin of some predators to "assimilate" their nature: cross-dressing-inanimal as a mechanism that turned the body itself into a metaphor. Consequently, the idea of camouflage becomes important as a figure of mimetic rhetoric. I am referring to bodies in disguise where a deceiving or simulating mechanism has become evident. The "trick" of cross-dressing in animal forms is a construction of a rhetorical order that emphasizes the similarity and replay of cultural and natural gestures (Barei 2015: 58). Following this logic, the body becomes a metaphorical object in order to explain a social behaviour: its basic principle is the translation of an animal morphology into a cultural phenomenon.

\footnotetext{
1 For example, the architectonic form of the ceremonial center of Chavín de Huántar, Peru, represents a jaguar.

2 It is important to consider that, thanks to the implementation of Christianity, many local myths presented an hybridization of features that combine elements of the Judeo-Christian tradition with the mythological and religious system of Aboriginal communities.
} 
Likewise, the shapes of lycanthropy (shape-shifters) establish an intimate bond with a presumed "animal violence" of certain subjects - cf. the representation of berserkers in Nordic traditions (Lotman 2004: 40). In Western culture, the metamorphosis into animals allows humans to somehow justify those behaviours in which excessive aggressiveness must find ways of appropriation and translation. In the aboriginal imagination, it is no coincidence that the figure of the RunaUturunco becomes relevant in the process of colonization of native peoples. In these historical cases, culture employs an operation by which it is possible to semiotize a "natural other" (the predator, a cougar or a jaguar), from a social perspective that produces border subjects that explain a "transference between spheres" (Barei, Molina Ahumada 2008: 10). In this way, I can refer to a strong intervention where 'the human' is modelled in an animal tone, a resource that is constantly applied in political discourses.

Also, it is interesting to note that in the 20th century, Uturunco was the name of the first guerrilla group of Argentina. In 1959, a group of young people under the command of Colonel "Puma" Serevalle initiated a series of political actions of extreme violence as a result of a new political situation in Argentina following the exile of President Juan Domingo Perón (1895-1974). Under the motto PUMA ${ }^{3}$, this militant group remained hidden in the jungle where they planned their activist agenda. ${ }^{4}$

Another example of the metaphorization of predation can be brought out in the classic literature of Argentinean culture. In 1845, Domingo Faustino Sarmiento (1811-1888), who was president of Argentina in the late 19th century, published his major work in which he details the social and political situation of Argentina, a country where the descendants of Spaniards, Creoles and Aboriginal people lived in a dynamic culture. In Civilización y Barbarieen las Pampas Argentinas ${ }^{5}$, Sarmiento narrated the life of one of the most controversial political leaders: Facundo Quiroga (1788-1835). In Chapter V, Sarmiento (2006: 110) describes Quiroga's life, emphasizing the event that will later give him the nickname 'Tigre de los Llanos' ('The Tiger of the Plains'). In his narrative, Sarmiento relates Quiroga's encounter with a yaguareté (a jaguar), an animal that the Argentinian president named 'tigrecebado'.

\footnotetext{
3 "Por Una Argentina Mejor" ("For a Better Argentina" in Spanish).

4 On the other hand, it is interesting to note that in its English sense, 'cougar' (Puma) is defined by Oxford Dictionary (2010) as "an older woman seeking a sexual relationship with a younger man". This use makes it possible to think about a connection between predator metaphors and an understanding of sexuality. In many languages, it is very common that animal metaphors establish their source in sexuality and seduction.

5 Simplified as Civilización o Barbarie (Civilization or Barbarism in Spanish) and also known just as Facundo.

6 In the popular culture of Argentina, cebado is the Spanish name given to the man-eating animals. Also, it is interesting to note that the jaguar is often confused with the tiger (just as
} 
Chased by the predator, Quiroga hid in a tree until his friends came to the rescue. In this encounter, human and beast are objects of an ethological synchronization; for instance, in "the gaucho's constrained attitude, and the fearful fascination exercised over him by the fixed and bloodthirsty stare of the tiger, which irresistibly attracted and retained his own glances" (Sarmiento 2006:115; my translation, A. G. P.).

In order to construct a political analogy, Sarmiento operates a progressive identification between the tiger and Quiroga. For instance, the brown spots of the former are "spots of character" in the latter. In this political text that borders with fiction, Facundo Quiroga suffers an "animal masquerading" that refers to characters whose behaviours have confusing zoomorphic features, revealing the animalistic nature of human beings at a mythological level (Nekludov 2002: 245). Sarmiento interprets the political leader (his ideological enemy) as a subject endowed with "fierce and bloody instincts", destructive behaviours of an innate nature (2006: 122; my translation, A. G. P.). In previous investigations of this topic, I observed how the notion of instinct functions culturally to explain a predatory act "driven" by the mechanisms of power (Gómez Ponce 2014). According to Michel Foucault (1995: 19), cultures define an alleged innate nature through instincts: an understanding of the social behaviour which is actually operated by a policy of instincts. In this kind of operations, instincts can be thought of as the effect of some "nature", a kind of intervention of biological forces that allow societies to explain behaviours of certain subjects such as criminals, murderers or rapist, among others. In Quiroga, Domingo Sarmiento finds an "environmental determinism" which is, in fact, the product of the naturalization of behaviours that should be understood as social, cultural, and, particularly, political operations. In this sense, his political enemy is a subject of a "system of instinctive submissions". As the tiger, Facundo Quiroga "is the natural man, as yet not used either to repress or disguise his passions; he does not restrain their energy but gives free rein to their impetuosity" (Sarmiento 2006: 123; my translation, A. G. P.).

In Sarmiento's diatribe, "primitive barbarism" (according to the author, the original character of the human race) is manifest in the Argentinean desert. ${ }^{7}$ According to Sarmiento, the civilization/barbarism antinomy determines a way of interpreting the natural order that is built "in these regions where man must contend with this animal for dominion over nature" (Sarmiento 2006: 114; my translation, A. G. P.). As Elena

the cougar is with the lion). These alternations are very common in the scientific and literary discourses of the period in question.

7 In fact, Argentina has no deserts. In this period, it was common to attribute desert features to the South of the country which, not inhabited by the descendants of Spaniards and Creoles, was still populated by Aboriginal natives (who, as can be supposed, were not considered citizens of the nation). In the next decades, the policy of Sarmiento's presidency will build the foundations of a project to eradicate Amerindian communities: a bloody massacre known as the Conquest of the Desert that killed thousands of natives (Pigna 2004:323). 
Pérez (2008: 45) has observed, in this kind of representation, metaphors are used with the intent to erase the "taint of animality" under the conception that "civilizing is taming".

In this metaphor, Quiroga's violence is an animal feature that has to be tamed, and hunting him is a political witch-hunt. Considering aggression as a common practice, the human/animal tension is traced by Sarmiento through an animalistic semiotization of the cultural other, an operation still performed in contemporary political discourses. According to the Argentinean critic Martin Kohan (1999), Sarmiento's Civilización o Barbarie is a "semiotic defeat" that looked for the political domestication of the "unleashed animal" which threatens to return as a pack: the barbarian announcing the arrival of the entire horde. However, Kohan notes that animal aggression also takes place as an authorized violence in other kinds of textualities: in other semiotic mechanisms to tame the predatory nature, namely, in the form of spectacle in mass culture. For this reason, in a third and final instance, the sports world is taken as an example.

It is a well-known fact that in sports, names of natural species are frequently used as team names. Argentina possesses a varied zoo: Gallos (Cocks), Dogos (Argentinean Dogo), Murciélagos (Bats), Cuervos (Crows), for football teams; and Leonas (Lionesses) for the national hockey team, among others. In order to read the animal metaphor in this kind of cultural forms, I select the national rugby team: the UAR, Unión Argentina de Rugby (Argentina Rugby Union). While the logo of the team is an image of a jaguar (sported in all promotional merchandise), the team is internationally known as "Los Pumas" ("The Cougars") due to a confusion in 1965 by the South African press (Arcucci 2013: 56). The team uses the names of these feline predators to shape an entire animalistic semantic field in constructions such as 'poner legarra al partido' ('to put claw on the match') or 'el himno nacionales un grito de guerra, un rugido' ('the national anthem is a cry of war, a roar').

It is in advertising that the implementation of a predator-based metaphorical system becomes more visible. Examples of this are the advertisements of the 2013 Rugby Championship, which gave rise to numerous plays upon words with the representation of the cougar. These advertisements show, in the beginning, a sort of documentary in which a cougar encounters different prey represented by the animals which their opponents are named after: for the South African team, the springbok; for Australian one, the wallaby; and for New Zealand, the kiwi ${ }^{8}$. In all cases, the cougar begins the chase and the prey flees because, as the narrator explains, "it knows that a cougar never gives up" and "if there is one thing difficult in this world, it is escaping from a cougar". Afterwards, scenes of real matches are introduced, announcing the next encounter in the championship. Thus, a similarity

8 Advertisements are available on the Youtube channel of Renault Argentina, official sponsor of the team. Retrieved August 15, 2015, from http://www.youtube.com/user/RenaultArg/videos. 
is constructed rugby players and species of the natural world, that synchronizes the hunting sequence with the sports practice.

It is highly probable more is meant with this. According to the hypothesis of the philosopher José Ortega y Gasset, the germ of ludic behaviour is present in the hunting practices of early hominids, and every sporting event has the inspiring principle of perpetuating the past, when humanity was still in the "orbit of animal existence" (1942: 476; my translation, A. G. P.). In this sense, it is possible to assume that cultural phenomena such as sports remind humans of their hunter predator ethos. Players, predators competing for a ball and a territory in the field, show zoomorphic features that mark their animal nature not only through their physical appearance but also through their aggressive behaviour. In a sport such as rugby (where violence is extreme), superiority is exhibited, reminding us of the strict and hierarchical order established in all species based on body posture, size, and, especially, aggressiveness. Each match of the Pumas is highly encoded by a marked system of gestures and positions that determine a particular language, a language that is similar to those behaviours that have a significant dialogic character. According to Roland Barthes' What is Sport? (2007: 41), sports involve competition that is performed with excessive gestures, where body is the base-sign. In these cultural practices, human beings test themselves: they face nature in a struggle based on the demonstration of superiority.

\section{Conclusions: New questions about the human condition}

According to Juri Lotman (1987: 45), natural environment is the space where the individual is the sender and receiver of informational flows (that is, exchanges with the environment or between/within species). This coincides with Thomas Sebeok's (2001: 11) view who stated that living beings share a "default mode" of communication (corporal and ethological) that does not manifest verbally. In their cultures, humans have found complex forms to express the interaction with other beings. It is reasonable to think that the appropriation of animal behaviour through certain zoomorphic metaphors supposes that humans and other beings somehow exchange some kind of information. Semiotization of these semiotic encounters is reflected in the "rhetoric order" of culture. With the ability to create, model and fictionalize reality, humans could differentiate the individual from the collective, the self from the common, the "I" from "all other less than I", and culture from nature (Lotman 2004: 31). This distinction also generates another mechanism that highlights the ability to be an individual and to represent someone else at the same time. It reflects the capacity to create metaphors, which allows all human beings to position themselves in "the role of the cultural other" and assimilate otherness, as cultural texts show on a daily basis. 
To conclude, ecosemiotics gives us a framework to think about how humans are able to transpose the strategies and mechanisms of the animal world to become, in their cultural manifestations, predators. In order to illustrate this, I have discussed semiotic operations in which the category of 'predator' has been used as a cultural mechanism of metaphorization of aggressiveness. In order to emphasize certain behaviours that are not admitted into the canon of "normality", metaphors are used to connote an alleged "nature" in human beings. For authors like Michel Maffesoli (2012: 10), violence is an anthropological constant that supports the existence of the "human animality" which the West, over the centuries, locked (or tried to lock) into the idea of the rational subject. Consequently, "stories and legends, tribal traditions, movies and other choreographies show that fighting is an anthropological structure that makes us see that, in human beings, there is animality too" (Maffesoli 2012: 12, my translation, A. G. P.). Social forms of human violence are linked with animal behaviour by using predator as a cultural category as a "bridge" that generates a series of recurring predatory figures problematizing the human condition: for instance, mythological figures, political enemies or rugby players in which the metaphor functions as mechanism of translation.

According to Silvia Barei (2013), the texts of culture provide an answer, a way of thinking about the human condition in relation to other species by referring to different types of practices, such as hunting, competing, symbiosis, the delimitation of territory or the construction of sociality. This kind of thinking provides us a cultural interpretation of the animal that still can be found in humans:

We are animals, we belong in the animal world. We descended from some ancient hominid that one day climbed down from the trees and began walking upright. But we are creative animals: we are cruel and violent. We have the ability to kill in ways different from those of other animals. We do it not only to feed or to defend ourselves, but for pleasure, fun, or perversion (Barei 2013: 215; my translation, A. G. P.).

In conclusion, the study of metaphorical systems from the ecosemiotic point of view makes it possible to investigate how culture has tried to resolve the tension with the animal world since ancient times. In numerous textual representations, the culture/nature boundary is traced as a "place of passage" between the human and the zoomorphic world that determines a symbiotic alliance with other species. Finally, what seems to be emerging are complex and novel questions, "concerning the double nature of man as being inserted in nature but not limited by it" (Lotman 2004: 44). 


\section{References}

Arcucci, Daniel 2013. Los Pumas, crónicas de una pasión argentina. Buenos Aires: Editorial La Nación.

Ardrey, Robert 1976. The Hunting Hypothesis: A Personal Conclusion Concerning the Evolutionary Nature of Man. Atheneum: New York.

Baker, Steve 1993. Picturing the Beast. Animals, Identity and Representation. Champaign: University of Illinois Press.

Barbosa, Pedro; Castellanos, Ignacio 2005. The nature of predation and predator-prey interaction. In: Barbosa, Pedro; Castellanos, Ignacio (eds.), Ecology of Predator-Prey Interactions. New York: Oxford University Press, 1-2.

Barei, Silvia 2013. Pistas para abrirse caminos por la selva (humana). In: Barei, Silvia (ed.), Seminario de Verano I. La pregunta por lo humano. Córdoba: Ferreyra Editor, 213-218.

- 2015. Los hombres y los mundos de ficción. In: Barei, Silvia (ed.), Seminario de Verano III. El Hombre y los Mundos de Ficción. Córdoba: Ferreyra Editor, 11-32.

Barei, Silvia; Gómez Ponce, Ariel 2014. Cultura y formas de la vida. Perspectivas teóricas. Córdoba: Ferreyra Editor.

Barei, Silvia; Molina Ahumada, Pablo 2008. Pensar la Cultura I. Perspectivas Retóricas. Córdoba: Ferreyra Editor.

Barei, Silvia; Pérez, Elena; Molina Ahumada, Pablo; Leunda, Ana Inés; Villa, María José (eds.) 2006. El orden de la cultura y las formas de la metáfora. Córdoba: Ferreyra Editor.

Bossi, Elena 2004. Seres mágicos que habitan en la Argentina. San Salvador de Jujuy: Editorial Universidad Nacional de Jujuy.

Barthes, Roland 2007. What is Sport? New Haven: Yale University Press.

- 2009[1986]. Lo obvio y lo obtuso: imágenes, gestos, voces. Buenos Aires: Editorial Siglo XXI.

Colinvaux, Paul 1978. Por qué son escasas las fieras. Madrid: HermannBlume Ediciones.

De Man, Paul 1979. Allegories of Reading. New Haven: Yale University Press.

Dillehay, Tom; Kaulicke, Peter 1984. Aproximación metodológica: el comportamiento del jaguar y la organización socio-espacial humana. Relaciones de la Sociedad Argentina de Antropología 16: 27-36.

Douard, John; Schultz, Pamela 2012. Monstrous Crimes and the Failure of Forensic Psychiatry. New Brunswick: Springer.

Foucault, Michel 1995[1977]. Discipline and Punish: The Birth of Prison. London: Penguin Books.

Fromm, Erich 1992[1973]. The Anatomy of Human Destructiveness. De Gruyter Mouton: Berlin.

Gibbs, Raymond 1994. The Poetics of Mind: Figurative Thought, Language and Understanding. Cambridge: Cambridge University Press.

Genette, Gérard 1996. Figures III. Paris: Editions du Seuil.

Gómez de Silva, Guido 1985. Breve Diccionario Etimológico de la Lengua Española. México: Fondo de Cultura Económica.

Gómez Ponce, Ariel 2013. El devenir animal. El depredador como manifestación cultural. In: Barei, Silvia (ed.), Seminario de Verano I. La pregunta por lo humano. Córdoba: Ferreyra Editor, 93-123. 
- 2014. El instinto de la desobediencia. El criminal como sujeto de instintos. In: Barei, Silvia (ed.), Seminario de Verano II. Proyecto Prometeo: violencia, desorden y rebeldía. Córdoba: Ferreyra Editor, 113-147.

Haldi, Stacy Bergstrom 2003. Why Wars Widen: A Theory of Predation and Balancing. London: Frank Cass Publisher.

Ivanov, Vyacheslav 2002. Leopardo, onza, pantera. In: Acosta, Rinaldo (ed.), El árbol del mundo. Diccionario de imágenes, símbolos y términos mitológicos. La Habana: Casa de las América/Criterios, 241.

Kristeva, Julia 1982. Powers of Horror: An Essay on Abjection. New York: Columbia University Press.

Kohan, Martín 1999. Los animales domésticos. In: Zubierta, Ana M. (ed.), Letrados iletrados. Apropiaciones y representaciones de lo popular en la literatura. Buenos Aires: Eudeba, 7787.

Kruuk, Hans 2002. Hunter and Hunted: Relationships between Carnivores and People. New York: Cambridge University Press.

Kull, Kalevi 1998. Semiotic ecology: Different natures in semiosphere. Sign Systems Studies 26: 344-371.

Lakoff, George; Johnson, Mark 1980. Metaphors We Live By. Chicago: University of Chicago Press.

Lakoff, George 2004. Don't Think of an Elephant: Know Your Values and Frame the Debate. Ontario: Chelsea Green Publishing Company.

Lorenz, Konrad 2005[1966]. On Aggression. London: Routledge Classics.

Lotman, Juri 1987. Natural Environment and Information. In: Kull, Kalevi; Tiivel, Toomas (eds.), Lectures in Theoretical Biology. Tallinn: Valgus, 45-47.

- 1990. Universe of the Mind: A Semiotic Theory of Culture. London: Tauris.

- 2000. La Semiosfera III. Madrid: FrónesisCátedra.

- 2004. Culture and Explosion (Semiotics, Communication and Cognition). Berlin: De GruyterMouton.

Maffesoli, Michel 2009. Ensayos sobre la violencia banal y fundadora. Buenos Aires: DedadusEditores.

Maran, Timo 2001. Mimicry: Towards a semiotic understanding of nature. Sign Systems Studies 29(1): 325-339.

Martinelli, Darío 2010. A Critical Companion to Zoosemiotics. Dordrecht: Springer.

Nekludov, Serguei. 2002. Transmutacionismo. In: Acosta, Rinaldo (ed.), El árbol del mundo. Diccionario de imágenes, símbolos y términos mitológicos. La Habana: Casa de las América/ Criterios, 432-434.

Nietzsche, Friedrich 2012[1873]. On Truth and Lies in a Nonmoral Sense. New York: CreateSpace Independent Publishing Platform.

Nöth, Winfried 1996. Ecosemiotics. Sign Systems Studies 26: 332-343.

- 2001. Ecosemiotics and semiotics of nature. Sign Systems Studies 29(1): 71-81.

Ortega y Gasset, José 1942. A "Veinte años de caza mayor", del Conde de Yebes. Obras completas. (Vol. 5.) Madrid: Editorial Revista de Occidente.

Oxford Dictionary of English. Third Edition 2010. (Stevenson, Angus, ed.). New York: Oxford University Press. 
Pérez, Elena 2008. Retóricas de la deshumanización. Córdoba: Ferreyra Editor. Pigna, Felipe 2004. Mitos de la Historia Argentina II. Buenos Aires: Planeta.

Ricoeur, Paul 1975. The Rule of Metaphor. Toronto: University of Toronto Press.

Roberts, Edward; Pastor, Bárbara 1996. Diccionario Etimológico Indoeuropeo de la Lengua Española. Madrid: Alianza.

Sarmiento, Domingo Faustino 2006[1845]. Facundo. Buenos Aires: Losada.

Sebeok, Thomas 2001. Signs: An Introduction to Semiotics. Toronto: University of Toronto Press.

Sommer, Robert; Sommer, Barbara A. 2001. Zoomorphy: Animal Metaphors for human personality. Anthrozoös 24(3): 237-248.

Tipler, Caroline 2013. Kitten and Cougars. The Effect of Distinct Dehumanizing Metaphors for Women on Perception and Behavior. Department of Psychology: Tulane University.

Toporov, Vladimir. 2002. Animales. In: Acosta, Rinaldo (ed.), El árbol del mundo. Diccionario de imágenes, símbolos y términos mitológicos. La Habana: Casa de las América/Criterios, 23-35.

Valverde Valdés, María del Carmen 1996. Jaguar y chamán entre los mayas. Alteridades 6(12): 27-31.

\section{Экосемиотические аспекты зооморфных метафор. Человек как хищник}

На протяжении всей истории создавались текстуальные репрезентации границы между человеком и животным, используя для этой цели и характеристики хищников. Поведение хищника остается повторяющимся мотивом, который появляется из метафорического понимания в культурном воображении. В исследовании этой тематики может помочь экосемиотика, позволяющая понять, как с помощью определенного хищного поведения создаются значения и как предполагаемые «животные наклонности» с помощью метафор переводятся, адаптируются к различным культурным текстам. В качестве иллюстрации рассматриваются некоторые метафоры хищника в аргентинской культуре. Для примера можно привести два вида хищников пуму и ягуара, которые стали основой культурных переводов, распространенных до наших дней. Эти переводы представляют собой форму, через которую культура метафоризирует агрессивность и интерпретирует определенные виды, исходя из исторической и идеологической перспективы. Аргентинские случаи преподносят нам моральный урок, показывая, как культурный «другой» считался культурно и биологически неполноценным. Примеры из латиноамериканской культуры показывают, как метафоры хищника вводят напряженность в пограничную сферу между человеком и животным. 


\section{Zoomorfistlike metafooride ökosemiootilised aspektid. Inimene kui kiskja}

Läbi ajaloo on inimese/looma piirjuhtude tekstuaalsete representatsioonide loomisel kasutatud kiskjalikke tunnusjooni. Selles mõttes on kiskjalik käitumine jäänud korduvaks motiiviks, mis kujuneb kultuurilises kujutlusvõimes metafoorilisest mõistmisest. Ökosemiootiline lähenemine võib selle teema uurimisel kasulikuks osutuda, sest võimaldab meil mõista, kuidas konkreetsed kiskjalikud käitumised tähendusi loovad: teisisõnu, kuidas väidetavad "loomalikud kalduvused" metafooride kaudu erinevatele kultuuritekstidele kohandatakse (tõlgitakse) ning retooriline korrastatus organiseeritakse. Selle illustreerimises vaadeldakse kiskjametafoore Argentiina kultuuri kuuluvates tekstides. Kaks liiki, puuma ja jaaguar, kujutavad endast konkreetset näidet, mis on olnud aluseks kultuurilistele tõlgetele, mis on laienenud ja levinud tänapäevani. Need tõlked kujutavad endast vormi, mille kaudu kultuur agressiivsust metaforiseerib ning teatud liike oma ajaloolisest ja ideoloogilisest perspektiivist lähtuvalt interpreteerib. Vaadeldavad Argentiina juhtumid annavad meile kõlbelise õppetunni, mis näitab, kuidas ajalugu kultuurilist 'teist' kultuuriliselt ja bioloogiliselt alaväärtuslikuks on pidanud. Ladina-Ameerika näidete varal vaatlen, kuidas kiskjametafoorid pingestavad inimese ja looma vahelist piiriala. 